4 Schlegel N, Maclouf J, Loirat C, et al. Absence of plasma prostacyclin stimulating activity deficiency in hemolytic uremic syndrome. $\mathcal{F}$ Pediatr ciency in hemolycic

5 Levin M, Elkon KB, Nokes TJ, et al. Inhibitor of prostacyclin production in sporadic hae-
molytic uraemic syndrome. Arch Dis Child molytic uraem

6 Siegler RL, Smith JB, Lynch MB, Mohammad $\mathrm{SF}$. Prostacyclin production following in vitro mixing of normal with hemolytic uremic syndrome serum. West $\mathcal{F}$ Med 1988;149:37-9.

Interleukin-1 $\alpha$ and soluble interleukin-2 receptor in atopic dermatitis

SIR,-Dr Agata and colleagues reported enhanced interleukin-2 (IL-2) activity in blood mononuclear cells from patients with food sensitive atopic dermatitis following allergen exposure. ' Soluble interleukin-2 receptor (sIL-2R) is an indirect marker of $\mathbf{T}$ cel activation by IL- 2 and raised concentrations have previously been described in adults with atopic dermatitis. ${ }^{2}$ However, in vitro studies suggest that IL-2 secretion by $\mathrm{T}$ helper cells is not only antigen driven but it is also dependen on interleukin-1 (IL-1) expression by cells of the macrophage/monocyte series; IL-1 also upregulates the expression of high affinity receptors for IL-2 on T helper cells type $1 .^{3}$ In order to investigate this hypothesis, we measured IL-1 $\alpha$ and sIL-2R using an ELISA technique. Twenty three children were assessed: 11 with atopic dermatitis and 12 non-atopic normal controls. The results are shown in the table.

\begin{tabular}{|c|c|c|c|}
\hline & Controls & $\begin{array}{l}\text { Atopic } \\
\text { dermatitis }\end{array}$ & $\begin{array}{l}\text { Unpaired } t \\
p \text { value }\end{array}$ \\
\hline $\begin{array}{l}\text { Mean age (years) } \\
\text { Range } \\
\text { IL-1 } \alpha \text { (pg/ml) } \\
95 \% \text { CI } \\
\text { sIL-2R (U/ml) } \\
95 \% \text { CI }\end{array}$ & $\begin{array}{c}9 \cdot 2 \\
4-14 \\
163 \\
56 \text { to } 269 \\
189 \\
75 \text { to } 301\end{array}$ & $\begin{array}{l}8 \cdot 6 \\
4-16 \\
369 \\
232 \text { to } 505 \\
377 \\
262 \text { to } 492\end{array}$ & $\begin{array}{l}\text { NS } \\
\mathrm{p}<0.02 \\
\mathrm{p}<0.02\end{array}$ \\
\hline
\end{tabular}

$\mathbf{C I}=$ confidence interval.

There was a strong direct correlation between IL- $1 \alpha$ and sIL-2R $(r=0.67, p<0.001)$ which suggests that expression of the two are dependent. While no apparent relationship existed between either cytokine concentration and disease severity using the criteria of Rajka and Langeland ${ }^{4}$ or IgE concentrations, our results demonstrate that there is enhanced endogenous secretion of IL-1 $\alpha$, and increased stimulation of IL-2 receptors, in children with atopic dermatitis. These findings suggest that these cytokines may contribute to the inflammatory process in atopic dermatitis and are consistent with the observations of Dr Agata and colleagues.

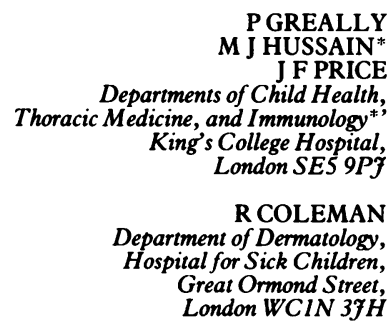

1 Agata H, Kondo N, Fukutomi O, Shinoda S, Orii T. Interlukin-2 production of lymphoctes in food sensitive atopic dermatitis. Arch Dis Child 1992;67:280-4.

2 Colver GB, Symons JA, Duff GW. Soluble interleukin-2 receptor in atopic eczema. $B M \mathcal{J}$ 1989;298:1426-8.

3 Male D, Champion B, Cooke A, Owen $M$. Antigen presentation to $T$ cells. Advanced immunology. London: Gower Medical Publishing, 1991:8.11.

4 Rajka G, Langeland T. Grading of the severity of atopic dermatitis. Acta Derm Venereol (Stockh) atopic dermatitis. Acta

Pulse oximetry reference values at high altitude

SIR,-Lozano et al in their article on pulse oximetry reference values at high altitude conclude that their reference values could be used for the interpretation of oxygen saturation at high altitude in Bogota and other cities at a similar altitude. ${ }^{1}$ However, the authors have failed to take into account potential sources of error.

The fall in arterial oxygen saturation at altitude is due to the fall in barometric pressure rather than the gain in altitude per se. There is a corresponding fall in atmospheric oxygen tension $\left(\mathrm{Po}_{2}\right)$ with fall in barometric pressure (at $2000 \mathrm{~m}$ atmospheric $\mathrm{Po}_{2}=124.9$ $\mathrm{mm} \mathrm{Hg}(16.6 \mathrm{kPa})$ and at $3000 \mathrm{~m} \mathrm{Po}_{2}=110.2$ $\left.\mathrm{mm} \mathrm{Hg}(14.7 \mathrm{kPa})^{2}\right)$ such that the author's proposed reference ranges are not suitable for use at altitudes other than that of Bogota $(2640 \mathrm{~m})$ as even small changes in altitude will alter the availability of atmospheric oxygen and the arterial oxygen saturation.

Furthermore, at a given altitude the barometric pressure changes with local variations in weather and to a greater extent with the season such that in mid-summer the barometric pressure may be $11 \mathrm{~mm} \mathrm{Hg}(1.47 \mathrm{kPa})$ higher than in winter. ${ }^{3}$ Moreover, there is an equatorial bulge in the atmosphere such that the barometric pressure at a given altitude near the equator is higher than at the same altitude nearer the poles by $17 \mathrm{~mm} \mathrm{Hg}(2 \cdot 27 \mathrm{kPa}){ }^{4}$ These pressure variations will affect the partial pressure of oxygen in the atmosphere Although of little significance at sea level pressures, these changes in atmospheric $\mathrm{Po}_{2}$ in the already 'desaturated' infant at altitude may significantly affect arterial saturation.

Taking these observations into account the authors may find that there are both seasonal and latitudinal variations in arterial oxygen saturation along with the changes in barometric pressure such that their proposed reference ranges should be intrepreted with caution in summer and probably not used at all at latitudes or altitudes distant from Bogota.

Before recognition of these changes in barometric pressure with season and latitude the ascent of Everest ( $8848 \mathrm{~m}$ ) without supplementary oxygen was thought impossible. In 1978 Messner and Habeler proved the physiologists wrong. ${ }^{s}$

A J POLLARD The Children's Hospital,
Ladywood Middleway, Ladywood,

Birmingham Bl6 8ET

1 Lozano JM, Duque OR, Buitrago T, Behaine S Pulse oximetry reference values at high altitude. Arch Dis Child 1992;67:299-301.

2 International Civil Aviation Organisation. International Civil Aviation Organisation manual of
the ICAO standard atmosphere. 2nd Ed. Montreal, Quebec: International Civil Aviation Montreal, Quebec: In

3 Brunt D. Physical and dynamical meterology. 2nd Ed. Cambridge: Cambridge University Press, 1952:379.

4 West JB, Lahiri S, Maret KH, Peters RM, Pizzo CJ. Barometric pressure at extreme altitudes on Mi Everest: physiological significance. Fournal of Applied Physiology: Respiratory, Enviro mental and Exercise Physiology 1983;54:1188.

5 Messner R. Everest: expedition to the ultimate. London: Kaye and Ward, 1979.
Randomised trial of nutrition for preterm infants after discharge

SIR,-This interesting study draws attention to a possible need for preterm infants to be fed a slightly higher protein, mineral, and energycontaining milk in the first nine months after birth. ${ }^{1}$ However, the authors include detailed tables on feed tolerance, stool number, size and consistency, and skinfold thickness (which show no significant differences between diet groups) yet choose not to present any data on growth of weight, length, and head circumference on which they base their conclusions of a possible advantage for this specially designed formula. It is not enough to say that differences are apparent on visual inspection of the charts. In fact, looking at these it seems to me that if there are any differences at all they take place for length and head circumference only in the first few weeks: after this the curves virtually parallel each other. Weight does fall off in those fed the standard infant formula but only between about 6 and 18 weeks. Growth data have been meticulously collected and the statistical methods explained in detail but without giving information, on velocity or incremental growth, it is difficult to evaluate the findings of the study.

$$
\begin{array}{r}
\text { D P DAVIES } \\
\text { Department of Child Health, } \\
\text { University of Wales } \\
\text { College of Medicine, } \\
\text { Heath Park, } \\
\text { Cardiff CF4 4XN }
\end{array}
$$

1 Lucas A, Bishop NJ, King FJ, Cole TJ. Randomised trial of nutrition for preterm infants after discharge. Arch Dis Child 1992;67: infants

\section{Drs Lucas, Bishop, and Cole comment:}

Professor Davies seeks further information on growth in our study on postdischarge nutrition. The growth data collected at two weekly intervals are shown in our paper graphically (tabulation would have been cumbersome and the graphic data show centile placing). Given the small sample size, as expected, relatively few individual two week measurements showed a significant difference between groups. Nevertheless, in view of the consistently increased weight, length, and head circumference at every two week period up to 9 months' corrected age in the infants fed the fortified diet, we explored whether the overall growth trajectory was different between groups. This is a statistically robust procedure as, unlike the $t$ test comparisons of individual two weekly data points, we were taking the entire growth data set for each diet group into account. As growth trajectory is not linear, but curvilinear, growth velocity was calculated from a quadratic fit of the data. The significant differences we reported in length and weight gains between feed groups would be difficult to describe numerically, short of presenting equations for the quadratic curves, and we elected not to. We emphasise, however, that our statistical analyses confirm a clear advantage in weight and length gain $(p<0.005$ and $p<0.01$ respectively) for infants fed the fortified formula. The difference between groups in rate of head growth did not achieve significance, because the early divergence between groups tended to diminish later in the study period. Nevertheless, the head growth issue needs further exploration especially in view of our unpublished analyses that show a trend towards higher gross motor development scores at 9 months in infants fed the fortified 